\title{
Determinants of Violations in the SET50 Index Options Pricing Relationships: Put-Call-Futures Parity and Box Spread Tests
}

\author{
Woradee Jongadsayakul ${ }^{1}$ \\ ${ }^{1}$ Department of Economics, Faculty of Economics, Kasetsart University, Bangkok, Thailand \\ Correspondence: Woradee Jongadsayakul. E-mail: fecowdj@ku.ac.th
}

Received: November 16, 2017

Accepted: January 30, 2018

Online Published: February 26, 2018

doi:10.5539/ass.v14n3p1

URL: https://doi.org/10.5539/ass.v14n3p1

\begin{abstract}
Although SET50 Index Options, the only option product on Thailand Futures Exchange, has been traded since October 29, 2007, it has faced the liquidity problem. The SET50 Index Options market must offer a risk premium to compensate investors for liquidity risk. It may cause violations in options pricing relationships. This research therefore uses daily data from October 29, 2007 to December 30, 2016 to compare the violations in SET50 Index Options pricing relationships before and after change in contract specification on October 29, 2012 and investigate determinants of these violations using Tobit model. Two tests of SET50 Index Options pricing relationships, Put-Call-Futures Parity and Box Spread, are employed. The test results of Put-Call-Futures Parity show that the percentage and baht amount of violations in many cases are greater in the period before the modification of SET50 Index Options. Without transaction costs, we also see more Box Spread violations before contract adjustment. However, after taking transaction costs into account, there are more percentage and baht amount of Box Spread violations in the later time period. The estimation of Tobit model shows that the violation sizes of both Put-Call-Futures Parity and Box Spread, excluding transaction costs, depend on the liquidity of SET50 Index Options market measured by option moneyness and open interest. The SET50 Index Options contract specification, especially exercise price, also significantly affects the size of violations, though the direction of a relationship is not cleared.
\end{abstract}

Keywords: box spreads, efficiency, index option, put-call-futures parity

\section{Introduction}

In recent years, Thailand Futures Exchange (TFEX), under the Stock Exchange of Thailand group, has continuously been developed its products and generated more liquidity to meet market demand. On October 29, 2012, in order to provide more investment choices for investors and boost market liquidity, TFEX launched the new versions of SET50 Index Options. The strike price interval has been widened from 10 points to 25 points. The number of series per day has been reduced significantly from 5 in-the-money, 1 at-the-money, and 5 out-of-the-money series (5:1:5) to 2:1:2 and the contract size of the SET50 Index options now matches that of the SET50 Index futures, allowing for easier strategic trading. However, Jongadsayakul (2015) shows that its adjustment has a negative impact on option liquidity in terms of both trading volume and trading value due to a decrease in investment choices as a reduction in the number of strike prices and a loss of long-term investors as a removal of the two farthest quarterly months. Although total trading volume of SET50 Index options in 2016 increased $39.62 \%$ from the previous year to 428,810 contracts, it accounted for $0.62 \%$ of the total trading volume in TFEX. To compensate investors for liquidity risk, the SET50 Index Options market must offer a risk premium. It may cause violations in SET50 Index Options pricing relationships.

Some earlier studies (Lertburapa, 2015; Jongadsayakul, 2016; Jongadsayakul, 2017a; Jongadsayakul, 2017b) report many violations of the arbitrage conditions as applied to the SET50 index call and put options. However, the frequency of violations diminishes considerably after accounting for various market frictions (bid-ask spread, exchange fees, and brokerage commissions). Taking transaction costs into account, Lertburapa (2015) reports a number of riskless arbitrage opportunities under violation of Put-Call-Futures parity reduce significantly to 1 percent. Using bid-ask prices rather than closing prices, Jongadsayakul (2016) shows that the Box Spread arbitrage opportunities is less than $1 \%$, and none of them is persisted on the following trading day. Using the conditions of Call \& Put Spreads and Call \& Put Butterfly Spreads, the arbitrageurs can earn riskless profit with SET50 Index Put Options trading only (Jongadsayakul, 2017a; Jongadsayakul, 2017b). This paper focuses on the 
validity of two theoretical conditions on arbitrage-free pricing of options, Put-Call-Futures Parity and Box Spread. The test of Put-Call-Futures Parity provides evidence on the cross-market efficiency of the SET50 Index Futures and Options while the Box Spread test examines the relative pricing of index call and put options. However, the study extends earlier research by comparing the violations in the SET50 Index Options pricing relationships before and after the SET50 Index Options contract adjustment on October 29, 2012. We also examine whether features of the option, including liquidity, can explain deviations from pricing relations by employing Tobit model. The deviations from arbitrage relationships may reflect a liquidity risk premium as discussed in previous studies (e.g., Kamara \& Miller, 1995; Ackert \& Tian, 2001; Misra \& Misra, 2005; Vipul, 2006; Dixit, Yadav, \& Jain, 2011; Mohanti \& Priyan, 2013). Kamara and Miller (1995) use the dollar violation of arbitrage condition based on Put-Call Parity to determine the impact of liquidity on S\&P 500 Index Options pricing relationships. They show that variations in the deviations from Put-Call Parity are systematically related to proxies for liquidity risk in the stock and option markets. Consistent with the research by Kamara and Miller (1995), Ackert and Tian (2001) show that liquidity is clearly an important determinant of the size of violations in S\&P 500 Index Options pricing relationship. The violations are larger when liquidity is low as proxied by option moneyness, volume, and open interest. The studies by Misra and Misra (2005), Vipul (2006), Dixit et al. (2011), and Mohanti and Priyan (2013) analyze the mispricing of Nifty index options. Misra and Misra (2005) indicate that the violations of Put-Call Parity are more in case of deeply in the money or deeply out of the money options and for longer time to maturity. Vipul (2006), on the other hand, conducts Box Spread test and finds that the mispricing in Box Spread is higher for the option contracts with higher liquidity risk captured by the moneyness and the volatility of Nifty. The tests of lower boundary conditions of both call and put options are employed by Dixit et al. (2011) and Mohanti and Priyan (2013). The results reveal that violations are related with the liquidity of the options contract.

The remaining paper is organized as follows. The structures of Put-Call-Futures Parity and Box Spread are detailed in the second section. The sources of data and the methods adopted for identifying the mispricing in option contracts and the determinants of these violations are described in the third section. The findings are reported in the forth section, and the last section concludes the paper.

\section{Structures of Put-Call-Futures Parity and Box Spread}

There are several theoretical conditions on arbitrage-free pricing of options. This paper focuses on Put-Call-Futures Parity and Box Spread, which consist of both call and put options in the pricing relationships. Put-Call-Futures Parity condition concerns arbitrage across the futures and the options markets while Box Spread condition enforces pricing efficiency across call and put options. Options on the SET50 index are European, and the discussion below applies to European options only.

\subsection{Put-Call-Futures Parity}

Define $\mathrm{P}$ and $\mathrm{C}$ as the prices of a European put-call pair with exercise price $\mathrm{K}$ and time to maturity $\mathrm{t}, \mathrm{S}$ and $\mathrm{F}$ as the spot and futures prices of underlying asset, and $r$ as risk-free rate of interest. The Put-Call-Futures parity equation is as follows (Tucker, 1991):

$$
|\mathrm{P}-\mathrm{C}|=|\mathrm{K}-\mathrm{F}| \exp (-\mathrm{rt})
$$

Because options can be combined to create synthetic futures contracts, arbitrage process should ensure that the payoffs obtained from actual and synthetic futures strategies are identical. A long (short) synthetic futures requires buying a call (put) and writing a corresponding put (call). For a hedged portfolio consisting of a long futures contract and a short synthetic futures contract, its payoff at expiration (T) equals $\mathrm{K}-\mathrm{F}$ regardless of the value of $\mathrm{S}$ at expiration. The current value of this hedged portfolio must be the present value of $\mathrm{K}-\mathrm{F}$, where the discount rate is the riskless rate of interest. So we have $\mathrm{P}-\mathrm{C}=(\mathrm{K}-\mathrm{F}) \exp (-\mathrm{rt})$, which conforms to Equation (1). On the other hand, a combination of a short futures contract and a long synthetic futures contract has a payoff of $\mathrm{F}-\mathrm{K}$ for all possible values of the underlying asset price at the option's expiration. Its current value must be the present value of $\mathrm{F}-\mathrm{K}$, where the discount rate is the riskless rate of interest. So we have $\mathrm{C}-\mathrm{P}=(\mathrm{F}-\mathrm{K}) \exp (-\mathrm{rt})$, which also follows Equation (1).

If the Put-Call-Futures parity in Equation (1) is violated, one can make risk-free arbitrage profit by pursuing a long/short strategy.

\subsubsection{Long Strategy: $\mathrm{C}-\mathrm{P}-(\mathrm{F}-\mathrm{K}) \exp (-\mathrm{rt})>0$}

An arbitrageur can earn riskless profit by employing the long strategy, consisting of a long futures contract, a short synthetic futures contract, and borrowing the amount of $(\mathrm{K}-\mathrm{F}) \exp (-\mathrm{rt})$ when $\mathrm{F}<\mathrm{K}$ or investing the amount of $(\mathrm{F}-\mathrm{K}) \exp (-\mathrm{rt})$ when $\mathrm{F}>\mathrm{K}$. The long strategy generates total cash flow of $\mathrm{C}-\mathrm{P}-(\mathrm{F}-\mathrm{K}) \exp (-\mathrm{rt})$, 
which is positive, at the beginning and zero payoff at expiration.

Table 1. Cash flows of the long strategy

\begin{tabular}{cccc}
\hline Actions & Initial cash flows & \multicolumn{2}{c}{ Cash flows at expiration } \\
\cline { 3 - 4 } & & $\mathrm{S}_{\mathrm{T}} \leq \mathrm{K}$ & $\mathrm{K}<\mathrm{S}_{\mathrm{T}}$ \\
\hline Write call with $\mathrm{K}$ & $\mathrm{C}$ & - & $-\left(\mathrm{S}_{\mathrm{T}}-\mathrm{K}\right)$ \\
Long put with $\mathrm{K}$ & 0 & $\mathrm{~K}-\mathrm{S}_{\mathrm{T}}$ & - \\
Long futures & $-\mathrm{P}-\mathrm{K}) \exp (-\mathrm{rt})$ & $\mathrm{S}-\mathrm{K}$ & $\mathrm{S}_{\mathrm{T}}-\mathrm{F}$ \\
Investing/Borrowing & $\mathrm{C}-\mathrm{P}-(\mathrm{F}-\mathrm{K}) \exp (-\mathrm{rt})$ & 0 & $\mathrm{~F}-\mathrm{K}$ \\
\hline Total & & & 0 \\
\hline
\end{tabular}

\subsubsection{Short Strategy: $\mathrm{P}-\mathrm{C}-(\mathrm{K}-\mathrm{F}) \exp (-\mathrm{rt})>0$}

An arbitrageur can earn riskless profit by employing the short strategy, consisting of a short futures contract, a long synthetic futures contract, and investing the amount of $(\mathrm{K}-\mathrm{F}) \exp (-\mathrm{rt})$ when $\mathrm{F}<\mathrm{K}$ or borrowing the amount of $(\mathrm{F}-\mathrm{K}) \exp (-\mathrm{rt})$ when $\mathrm{F}>\mathrm{K}$. The short strategy offers total cash flow of $\mathrm{P}-\mathrm{C}-(\mathrm{K}-\mathrm{F}) \exp (-\mathrm{rt})$, which is positive, at the beginning and zero payoff at expiration.

Table 2. Cash flows of the short strategy

\begin{tabular}{cccc}
\hline Actions & Initial cash flows & \multicolumn{2}{c}{ Cash flows at expiration } \\
\cline { 2 - 4 } & & $\mathrm{S}_{\mathrm{T}} \leq \mathrm{K}$ & $\mathrm{K}<\mathrm{S}_{\mathrm{T}}$ \\
\hline Long call with $\mathrm{K}$ & $-\mathrm{C}$ & - & $\mathrm{S}_{\mathrm{T}}-\mathrm{K}$ \\
Write put with $\mathrm{K}$ & $\mathrm{P}$ & $-\left(\mathrm{K}-\mathrm{S}_{\mathrm{T}}\right)$ & - \\
Short futures & 0 & $\mathrm{~F}-\mathrm{S}_{\mathrm{T}}$ & $\mathrm{F}-\mathrm{S}_{\mathrm{T}}$ \\
Investing/Borrowing & $-(\mathrm{K}-\mathrm{F}) \exp (-\mathrm{rt})$ & $\mathrm{K}-\mathrm{F}$ & $\mathrm{K}-\mathrm{F}$ \\
\hline Total & $\mathrm{P}-\mathrm{C}-(\mathrm{K}-\mathrm{F}) \exp (-\mathrm{rt})$ & 0 & 0 \\
\hline
\end{tabular}

\subsection{Box Spread}

The Box Spread involves two pairs of puts and calls with different strike prices but the same underlying asset and the same expiration date. Define $\left(\mathrm{C}_{\mathrm{L}}, \mathrm{P}_{\mathrm{L}}\right)$ as the prices of a pair of call and put with a lower exercise price $\left(\mathrm{K}_{\mathrm{L}}\right)$ and $\left(\mathrm{C}_{\mathrm{H}}, \mathrm{P}_{\mathrm{H}}\right)$ as the prices of the other with a higher exercise price $\left(\mathrm{K}_{\mathrm{H}}\right)$. The Box Spread relation is just a simple algebraic combination of the put-call parity relationship for each option and can be expressed as follows:

$$
\mathrm{C}_{\mathrm{L}}-\mathrm{C}_{\mathrm{H}}+\mathrm{P}_{\mathrm{H}}-\mathrm{P}_{\mathrm{L}}=\left(\mathrm{K}_{\mathrm{H}}-\mathrm{K}_{\mathrm{L}}\right) \exp (-\mathrm{rt})
$$

For a hedged portfolio consisting of a bull call spread, purchasing a call with exercise price $\mathrm{K}_{\mathrm{L}}$ and simultaneously selling a call with exercise price $\mathrm{K}_{\mathrm{H}}$, and a bear put spread, selling a put with exercise price $\mathrm{K}_{\mathrm{L}}$ and simultaneously purchasing a put with exercise price $\mathrm{K}_{\mathrm{H}}$, its payoff at expiration (T) equal $\mathrm{K}_{\mathrm{H}}-\mathrm{K}_{\mathrm{L}}$ regardless of the value of $\mathrm{S}_{\mathrm{T}}$. The current value of this hedged portfolio must be the present value of $\mathrm{K}_{\mathrm{H}}-\mathrm{K}_{\mathrm{L}}$, where the discount rate is the riskless rate of interest. So we have $C_{L}-C_{H}+P_{H}-P_{L}=\left(K_{H}-K_{L}\right) \exp (-r t)$ as shown in Equation (2). On the other hand, a combination of a bear call spread, selling a call with exercise price $\mathrm{K}_{\mathrm{L}}$ and simultaneously purchasing a call with exercise price $\mathrm{K}_{\mathrm{H}}$, and a bull put spread, purchasing a put with exercise price $\mathrm{K}_{\mathrm{L}}$ and simultaneously selling a put with exercise price $\mathrm{K}_{\mathrm{H}}$, has a payoff equal $\mathrm{K}_{\mathrm{L}}-\mathrm{K}_{\mathrm{H}}$ for all possible values of the underlying asset price at the option's expiration. Its current value must be the present value of $\left(\mathrm{K}_{\mathrm{L}}-\right.$ $\mathrm{K}_{\mathrm{H}}$, where the discount rate is the riskless rate of interest. We have $\mathrm{C}_{\mathrm{H}}-\mathrm{C}_{\mathrm{L}}+\mathrm{P}_{\mathrm{L}}-\mathrm{P}_{\mathrm{H}}=\left(\mathrm{K}_{\mathrm{L}}-\mathrm{K}_{\mathrm{H}}\right) \exp (-\mathrm{rt})$, which also follows Equation (2).

If the Box Spread relation in Equation (2) is violated, one can make risk-free arbitrage profit by pursuing a long/short box spread strategy.

2.2.1 Long Box Spread: $\mathrm{C}_{\mathrm{H}}-\mathrm{C}_{\mathrm{L}}+\mathrm{P}_{\mathrm{L}}-\mathrm{P}_{\mathrm{H}}+\left(\mathrm{K}_{\mathrm{H}}-\mathrm{K}_{\mathrm{L}}\right) \exp (-\mathrm{rt})>0$

An arbitrageur can earn riskless profit by employing the long box spread strategy, consisting of a bull call spread, a bear put spread, and borrowing the amount of $\left(\mathrm{K}_{\mathrm{H}}-\mathrm{K}_{\mathrm{L}}\right) \exp (-\mathrm{rt})$. The long box spread strategy generates positive initial cash flow, which equals $\left(\mathrm{C}_{\mathrm{H}}-\mathrm{C}_{\mathrm{L}}\right)+\left(\mathrm{P}_{\mathrm{L}}-\mathrm{P}_{\mathrm{H}}\right)+\left(\mathrm{K}_{\mathrm{H}}-\mathrm{K}_{\mathrm{L}}\right) \exp (-\mathrm{rt})$, and zero payoff at expiration. 
Table 3. Cash flows of the long box spread strategy

\begin{tabular}{ccccc}
\hline \multirow{2}{*}{ Actions } & \multirow{2}{*}{ Initial cash flows } & \multicolumn{3}{c}{ Cash flows at expiration } \\
\cline { 3 - 5 } & & $\mathrm{S}_{\mathrm{T}} \leq \mathrm{K}_{\mathrm{L}}<\mathrm{K}_{\mathrm{H}}$ & $\mathrm{K}_{\mathrm{L}}<\mathrm{S}_{\mathrm{T}} \leq \mathrm{K}_{\mathrm{H}}$ & $\mathrm{K}_{\mathrm{L}}<\mathrm{K}_{\mathrm{H}}<\mathrm{S}_{\mathrm{T}}$ \\
\hline Long call with $\mathrm{K}_{\mathrm{L}}$ & $-\mathrm{C}_{\mathrm{L}}$ & - & $\mathrm{S}_{\mathrm{T}}-\mathrm{K}_{\mathrm{L}}$ & $\mathrm{S}_{\mathrm{T}}-\mathrm{K}_{\mathrm{L}}$ \\
Write call with $\mathrm{K}_{\mathrm{H}}$ & $\mathrm{C}_{\mathrm{H}}$ & - & - & $-\left(\mathrm{S}_{\mathrm{T}}-\mathrm{K}_{\mathrm{H}}\right)$ \\
Write put with $\mathrm{K}_{\mathrm{L}}$ & $\mathrm{P}_{\mathrm{L}}$ & $-\left(\mathrm{K}_{\mathrm{L}}-\mathrm{S}_{\mathrm{T}}\right)$ & - & - \\
Long put with $\mathrm{K}_{\mathrm{H}}$ & $-\mathrm{P}_{\mathrm{H}}$ & $\mathrm{K}_{\mathrm{H}}-\mathrm{S}_{\mathrm{T}}$ & $\mathrm{K}_{\mathrm{H}}-\mathrm{S}_{\mathrm{T}}$ & - \\
Borrowing & $\left(\mathrm{K}_{\mathrm{H}}-\mathrm{K}_{\mathrm{L}}\right) \exp (-\mathrm{rt})$ & $-\left(\mathrm{K}_{\mathrm{H}}-\mathrm{K}_{\mathrm{L}}\right)$ & $-\left(\mathrm{K}_{\mathrm{H}}-\mathrm{K}_{\mathrm{L}}\right)$ & $-\left(\mathrm{K}_{\mathrm{H}}-\mathrm{K}_{\mathrm{L}}\right)$ \\
\hline Total & $\left(\mathrm{C}_{\mathrm{H}}-\mathrm{C}_{\mathrm{L}}\right)+\left(\mathrm{P}_{\mathrm{L}}-\mathrm{P}_{\mathrm{H}}\right)+\left(\mathrm{K}_{\mathrm{H}}-\mathrm{K}_{\mathrm{L}}\right) \exp (-\mathrm{rt})$ & 0 & 0 & 0 \\
\hline
\end{tabular}

Case 4: $\mathrm{C}_{\mathrm{L}}-\mathrm{C}_{\mathrm{H}}+\mathrm{P}_{\mathrm{H}}-\mathrm{P}_{\mathrm{L}}-\left(\mathrm{K}_{\mathrm{H}}-\mathrm{K}_{\mathrm{L}}\right) \exp (-\mathrm{rt})>0$

An arbitrageur can earn riskless profit by employing the short box spread strategy, consisting of a bear call spread, a bull put spread, and investing the amount of $\left(\mathrm{K}_{\mathrm{H}}-\mathrm{K}_{\mathrm{L}}\right) \exp (-\mathrm{rt})$. The short box spread strategy generates positive initial cash flow, which equals $\left(\mathrm{C}_{\mathrm{L}}-\mathrm{C}_{\mathrm{H}}\right)+\left(\mathrm{P}_{\mathrm{H}}-\mathrm{P}_{\mathrm{L}}\right)-\left(\mathrm{K}_{\mathrm{H}}-\mathrm{K}_{\mathrm{L}}\right) \exp (-\mathrm{rt})$, and zero payoff at expiration.

Table 4. Cash flows of the short box spread strategy

\begin{tabular}{ccccc}
\hline \multirow{2}{*}{ Actions } & Initial cash flows & \multicolumn{3}{c}{ Cash flows at expiration } \\
\cline { 2 - 5 } & & $\mathrm{S}_{\mathrm{T}} \leq \mathrm{K}_{\mathrm{L}}<\mathrm{K}_{\mathrm{H}}$ & $\mathrm{K}_{\mathrm{L}}<\mathrm{S}_{\mathrm{T}} \leq \mathrm{K}_{\mathrm{H}}$ & $\mathrm{K}_{\mathrm{L}}<\mathrm{K}_{\mathrm{H}}<\mathrm{S}_{\mathrm{T}}$ \\
\hline Write call with $\mathrm{K}_{\mathrm{L}}$ & $\mathrm{C}_{\mathrm{L}}$ & - & $-\left(\mathrm{S}_{\mathrm{T}}-\mathrm{K}_{\mathrm{L}}\right)$ & $-\left(\mathrm{S}_{\mathrm{T}}-\mathrm{K}_{\mathrm{L}}\right)$ \\
Long call with $\mathrm{K}_{\mathrm{H}}$ & $-\mathrm{C}_{\mathrm{H}}$ & - & - & $\mathrm{S}_{\mathrm{T}}-\mathrm{K}_{\mathrm{H}}$ \\
Long put with $\mathrm{K}_{\mathrm{L}}$ & $-\mathrm{P}_{\mathrm{L}}$ & $\mathrm{K}_{\mathrm{L}}-\mathrm{S}_{\mathrm{T}}$ & - & - \\
Write put with $\mathrm{K}_{\mathrm{H}}$ & $\mathrm{P}_{\mathrm{H}}$ & $-\left(\mathrm{K}_{\mathrm{H}}-\mathrm{S}_{\mathrm{T}}\right)$ & $-\left(\mathrm{K}_{\mathrm{H}}-\mathrm{S}_{\mathrm{T}}\right)$ & - \\
Investing & $-\left(\mathrm{K}_{\mathrm{H}}-\mathrm{K}_{\mathrm{L}}\right) \exp (-\mathrm{rt})$ & $\mathrm{K}_{\mathrm{H}}-\mathrm{K}_{\mathrm{L}}$ & $\mathrm{K}_{\mathrm{H}}-\mathrm{K}_{\mathrm{L}}$ & $\mathrm{K}_{\mathrm{H}}-\mathrm{K}_{\mathrm{L}}$ \\
\hline Total & $\left(\mathrm{C}_{\mathrm{L}}-\mathrm{C}_{\mathrm{H}}\right)+\left(\mathrm{P}_{\mathrm{H}}-\mathrm{P}_{\mathrm{L}}\right)-\left(\mathrm{K}_{\mathrm{H}}-\mathrm{K}_{\mathrm{L}}\right) \exp (-\mathrm{rt})$ & 0 & 0 & 0 \\
\hline
\end{tabular}

\section{Data and Methodology}

Using daily data from October 29, 2007 to December 30, 2016, the empirical investigation compares the violations in SET50 Index Options pricing relationships before and after change in contract specification on October 29, 2012. The analysis also includes determinants of these violations by employing Tobit model. The SET50 Index Options data set consists of closing prices (CL), bid prices (B), ask prices (A), exercise prices (K), time to maturity ( $\mathrm{t}$ ), volume, open interest, and moneyness. The SET50 Index Futures prices, including closing prices, bid prices, and ask prices, are used in testing Put-Call-Futures Parity. The riskless rate of interest (r) is proxied by Krung Thai's interest rate, minimum retail rate and savings interest rate for borrowing and investing, respectively. The violation tests of Put-Call-Futures Parity and Box Spread are examined under two scenarios. The closing prices of SET50 Index Options and Futures are used under Scenario 1 without transaction costs and are replaced by the bid-ask prices under Scenario 2 with transaction costs. Table 5 presents conditions for violations of two arbitrage pricing relationships, Put-Call-Futures Parity and Box Spread, under Scenario 1 and 2. If inequality conditions hold, the appropriate strategies generate positive initial cash flows or arbitrage profits, which equal the left side of inequalities. The inequality conditions are multiplied by the contract multiplier to convert the index point into the Baht value. The contract multipliers of the SET50 index options are 200 Baht per index point. However, Put-Call-Futures Parity explains the relationship between the prices of calls, puts, and futures on the same underlying asset and same expiration. Prior to the modification of SET50 futures contract size, the contract multiplier of SET50 Index Futures was 1,000 Baht per index point. This means five pairs of call and put options are required to construct a synthetic futures on the same underlying asset. The contract size of SET50 Index Futures was changed from 1,000 Baht per index point to 200 Baht per index point from May 6 , 2014 onward. Five pairs of call and put options are now related with five synthetic futures. Therefore, Put-Call-Futures Parity conditions must be multiplied by 1,000 to express in terms of Baht instead of index point. For Box Spread with two pairs of SET50 Index call and put options, we need to multiply conditions by the contract multiplier of 200 Baht per index point to convert the index point into the Baht value. 
Table 5. Conditions for arbitrage opportunities

\begin{tabular}{ccc}
\hline Strategy & $\begin{array}{c}\text { Scenario 1 } \\
(\text { exclude transaction costs })\end{array}$ & $\begin{array}{c}\text { Scenario 2 } \\
\text { (include transaction costs) }\end{array}$ \\
\hline Long Strategy & {$\left[\mathrm{C}^{\mathrm{CL}}-\mathrm{P}^{\mathrm{CL}}-\left(\mathrm{F}^{\mathrm{CL}}-\mathrm{K}\right) \exp (-\mathrm{rt})\right] \mathrm{x} 1,000>0$} & {$\left[\mathrm{C}^{\mathrm{B}}-\mathrm{P}^{\mathrm{A}}-\left(\mathrm{F}^{\mathrm{A}}-\mathrm{K}\right) \exp (-\mathrm{rt})\right] \mathrm{x} 1,000>0$} \\
Short Strategy & {$\left[\mathrm{P}^{\mathrm{CL}}-\mathrm{C}^{\mathrm{CL}}+\left(\mathrm{F}^{\mathrm{CL}}-\mathrm{K}\right) \exp (-\mathrm{rt})\right] \times 1,000>0$} & {$\left[\mathrm{P}^{\mathrm{B}}-\mathrm{C}^{\mathrm{A}}+\left(\mathrm{F}^{\mathrm{B}}-\mathrm{K}\right) \exp (-\mathrm{rt})\right] \times 1,000>0$} \\
Long Box Spread & {$\left[\left(\mathrm{C}_{\mathrm{H}}{ }^{\mathrm{CL}}-\mathrm{C}_{\mathrm{L}}{ }^{\mathrm{CL}}\right)+\left(\mathrm{P}_{\mathrm{L}}{ }^{\mathrm{CL}}-\mathrm{P}_{\mathrm{H}}{ }^{\mathrm{CL}}\right)\right.$} & {$\left[\left(\mathrm{C}_{\mathrm{H}}{ }^{\mathrm{B}}-\mathrm{C}_{\mathrm{L}}{ }^{\mathrm{A}}\right)+\left(\mathrm{P}_{\mathrm{L}}{ }^{\mathrm{B}}-\mathrm{P}_{\mathrm{H}}{ }^{\mathrm{A}}\right)\right.$} \\
Strategy & $\left.+\left(\mathrm{K}_{\mathrm{H}}-\mathrm{K}_{\mathrm{L}}\right) \exp (-\mathrm{rt})\right] \times 200>0$ & $\left.+\left(\mathrm{K}_{\mathrm{H}}-\mathrm{K}_{\mathrm{L}}\right) \exp (-\mathrm{rt})\right] \times 200>0$ \\
Short Box Spread & {$\left[\left(\mathrm{C}_{\mathrm{L}}{ }^{\mathrm{CL}}-\mathrm{C}_{\mathrm{H}}{ }^{\mathrm{CL}}\right)+\left(\mathrm{P}_{\mathrm{H}}{ }^{\mathrm{CL}}-\mathrm{P}_{\mathrm{L}}{ }^{\mathrm{CL}}\right)\right.$} & {$\left[\left(\mathrm{C}_{\mathrm{L}}{ }^{\mathrm{B}}-\mathrm{C}_{\mathrm{H}}{ }^{\mathrm{A}}\right)+\left(\mathrm{P}_{\mathrm{H}}{ }^{\mathrm{B}}-\mathrm{P}_{\mathrm{L}}{ }^{\mathrm{A}}\right)\right.$} \\
Strategy & $\left.-\left(\mathrm{K}_{\mathrm{H}}-\mathrm{K}_{\mathrm{L}}\right) \exp (-\mathrm{rt})\right] \times 200>0$ & $\left.-\left(\mathrm{K}_{\mathrm{H}}-\mathrm{K}_{\mathrm{L}}\right) \exp (-\mathrm{rt})\right] \times 200>0$ \\
\hline
\end{tabular}

If the violations are detected, we compare the frequency and size of violations in SET50 Index Options pricing relationships before and after change in contract specification on October 29, 2012. Moreover, to investigate the determinants of arbitrage condition violations, the paper uses Tobit model, developed by Tobin (1958), since when a pricing relationship holds, the dependent variable is censored or unobservable. The dependent variable in each regression is measured by the size of violations generated from the appropriate strategy (Long, Short, Long Box Spread, and Short Box Spread strategies), which equals to the left side of inequalities in the second column of Table 5, when ignoring transaction costs. The independent variables consist of two groups, the liquidity and the contract specification of the SET50 Index options, listed in Table 6.

Table 6. List of independent variables

\begin{tabular}{|c|c|c|}
\hline \multirow[b]{2}{*}{ Independent Variables } & Put-Call-Futures Parity & Box Spread \\
\hline & Long Strategy & $\begin{array}{l}\text { Short Box Spread } \\
\quad \text { Strategy }\end{array}$ \\
\hline \multicolumn{3}{|l|}{ Liquidity: } \\
\hline - Moneyness (M) & $(\mid \mathrm{S}-\mathrm{K} / \mathrm{S}) \times 100$ & $\left(\left|\mathrm{~S}-\mathrm{K}_{\mathrm{L}}\right| / \mathrm{S}\right)+\left(\mid \mathrm{S}-\mathrm{K}_{\mathrm{H}} / \mathrm{S}\right) \times 100 / 2$ \\
\hline - Volume (V) & $\begin{array}{l}\text { Sum of daily volume of SET50 Call and } \\
\text { Put Options with same exercise price K }\end{array}$ & $\begin{array}{l}\text { Sum of daily volume of SET50 Call and Put } \\
\text { Options with exercise prices } \mathrm{K}_{\mathrm{L}} \text { and } \mathrm{K}_{\mathrm{H}}\end{array}$ \\
\hline - Open interest $(\mathrm{O})$ & $\begin{array}{l}\text { Sum of open interest of SET } 50 \text { Call and Put } \\
\text { Options with same exercise price } \mathrm{K}\end{array}$ & $\begin{array}{l}\text { Sum of open interest of SET50 Call and Put } \\
\text { Options with exercise prices } \mathrm{K}_{\mathrm{L}} \text { and } \mathrm{K}_{\mathrm{H}}\end{array}$ \\
\hline \multicolumn{3}{|l|}{ Contract Specification: } \\
\hline - Time to maturity (T) & \multicolumn{2}{|c|}{$\begin{array}{l}\text { time between when violation in SET50 Index Options pricing relationship is detected and } \\
\text { when the contracts involved in SET50 Index Options pricing relationship mature }\end{array}$} \\
\hline - Exercise price $(\mathrm{E})$ & $\mathrm{K}$ & $\left(\mathrm{K}_{\mathrm{L}}+\mathrm{K}_{\mathrm{H}}\right) / 2$ \\
\hline $\begin{array}{l}\text { - Difference in exercise } \\
\text { prices (DE) }\end{array}$ & - & $\mathrm{K}_{\mathrm{H}}-\mathrm{K}_{\mathrm{L}}$ \\
\hline - Contract adjustment & \multirow{2}{*}{\multicolumn{2}{|c|}{$\begin{array}{l}\mathrm{D}=0 \text { if violation in SET50 Index Options pricing relationship is met before change in contract } \\
\text { specification on October 29, } 2012 \\
D=1 \text { if violation in SET50 Index Options pricing relationship is met after change in contract } \\
\text { specification on October } 29,2012\end{array}$}} \\
\hline dummy (D) & & \\
\hline
\end{tabular}

From Table 6, we expect greater violations in SET50 Index Options pricing relationships when liquidity risk in options trading is high. This usually occurs when options are far from the money. The first independent variable, Moneyness (M), therefore, measures how far an option is from the money by comparing the closing price of SET50 Index to exercise price. The other two independent variables, Volume (V) and Open interest (O), are also measures of option liquidity. The higher the daily volume, the more liquid the option contract becomes as compared to options with a lower daily volume. Moreover, the higher the open interest, the more liquid the option contract is thought to be. For option contract specification, there are 3 independent variables, Time to maturity (T), Exercise price (E), and Contract adjustment dummy (D), included in the Tobit regression. In case of Box Spread, one more independent variable, Difference in exercise prices (DE), is added since Box Spread 
involves options with two different exercise prices, $\mathrm{K}_{\mathrm{L}}$ and $\mathrm{K}_{\mathrm{H}}$. We hypothesize that option contract specification statistically affects the size of SET50 Index Options pricing violations

\section{Empirical Results}

In this section, we discuss the empirical results regarding the violation tests of Put-Call-Futures Parity and Box Spread and determinants of the size of violations in these option pricing relationships from October 29, 2007 to December 30, 2016.

Table 7 summarizes the test results of the Put-Call-Futures Parity and Box Spread under different hypothesis about transaction costs. Scenario 1 and 2 represent the tests conducted using, respectively, closing prices and the bid and ask prices. It can be noted that the inclusion of the bid-ask spread has reduced the frequency and size of violations. For the Put-Call-Futures Parity, the frequency of violations is approximately $4-7$ percent. Consistent with the results reported by Jongadsayakul (2016), the box spread arbitrage opportunities drop to less than $1 \%$.

Table 7. Violation tests of Put-Call-Futures Parity and Box Spread

\begin{tabular}{|c|c|c|c|c|}
\hline \multirow{2}{*}{ Violations } & \multicolumn{2}{|c|}{ Scenario 1 (exclude transaction costs) } & \multicolumn{2}{|c|}{ Scenario 2 (include transaction costs) } \\
\hline & Before & After & Before & After \\
\hline \multicolumn{5}{|c|}{ Panel A: Long Strategy } \\
\hline Number of observations & 6864 & 5039 & 6864 & 5039 \\
\hline Number of violations & 3382 & 2290 & 448 & 195 \\
\hline Percentages of violations & 49.27 & 45.45 & 6.53 & 3.87 \\
\hline Size of violations (Baht) & 2517.62 & 2335.19 & 926.46 & 753.11 \\
\hline \multicolumn{5}{|c|}{ Panel B: Short Strategy } \\
\hline Number of observations & 6864 & 5039 & 6864 & 5039 \\
\hline Number of violations & 3323 & 2506 & 374 & 230 \\
\hline Percentages of violations & 48.41 & 49.73 & 5.45 & 4.56 \\
\hline Size of violations (Baht) & 2530.46 & 2473.02 & 803.72 & 650.33 \\
\hline \multicolumn{5}{|c|}{ Panel C: Long Box Spread Strategy } \\
\hline Number of observations & 19463 & 9522 & 19463 & 9522 \\
\hline Number of violations & 9576 & 4637 & 17 & 33 \\
\hline Percentages of violations & 49.20 & 48.70 & 0.09 & 0.35 \\
\hline Size of violations (Baht) & 569.01 & 664.63 & 61.63 & 168.93 \\
\hline \multicolumn{5}{|c|}{ Panel D: Short Box Spread Strategy } \\
\hline Number of observations & 19463 & 9522 & 19463 & 9522 \\
\hline Number of violations & 9370 & 4200 & 14 & 22 \\
\hline Percentages of violations & 48.14 & 44.11 & 0.07 & 0.23 \\
\hline Size of violations (Baht) & 608.57 & 593.82 & 111.20 & 293.12 \\
\hline
\end{tabular}

Panels A and B of Table 7 contain the test results of Put-Call-Futures Parity violations. Many more violations of Put-Call-Futures Parity are observed before change in contract specification, as compared to the frequency violations after change in contract specification, except the case of short strategy without transaction costs. The baht amount of violations of Put-Call-Futures Parity in every case is also greater in the period before change in contract specification. When the Put-Call-Futures parity does not hold, the use of long strategy is more (less) common than the use of short strategy in the period before (after) contract modification. In addition, the frequency and size of Box Spread violations are reported in Panels C and D of Table 7. When there are no transaction costs, we see fewer Box Spread violations after contract adjustment. However, after taking transaction costs into account, there are more percentage and baht amount of Box Spread violations in the period after contract adjustment. When Box Spread condition is violated, long box spread strategy is used more common than short box spread strategy for both periods, before and after contract modification. Taking together, the results in Table 7 suggest that the impact of contract adjustment on violations in SET50 Index Options 
pricing relationships is mixed.

Next, Tobit regression analysis is conducted to examine the determinants of the size of violations in SET50 Index Options pricing relationships. Table 8 reports the estimation of the regression coefficient with $\mathrm{Z}$ statistic in parenthesis. At the bottom of Table 8 reports a p-value for testing the null hypothesis that the set of coefficients is simultaneously zero. In every regression, the p-value is zero, and we can reject the null hypothesis, which means our model provides a better fit than the intercept-only model. Liquidity, as measured by option moneyness or open interest, is clearly an important determinant of the size of violations in SET50 Index Option pricing relationships. As expected, the size of violations is larger when liquidity is low. Greater deviations from arbitrage pricing relationships are observed when options are farther from the money or open interest is low. Except the case of short box spread, volume does not significantly affect the size of violations. In addition, the second group of independent variables involves the contract specification of SET50 Index Options. Time to maturity has an impact only on the size of Box Spread violations, though the signs are mixed. Exercise price is also one of the important determinants. We use exercise price of a put-call pair in the Put-Call-Futures Parity relationship but include both the average exercise price and the difference in exercise prices for the Box Spread relationship. The sign of the estimated coefficient of exercise price is negative when employing long strategy and long box spread strategy, whereas its sign is positive when employing short strategy and short box spread strategy. Difference in exercise prices positively affects only the size of long box spread violation. The results also suggest that the option contract adjustment increases the size of violations only when employing long strategy and long box spread strategy.

Table 8. Tobit regression analysis of the determinants of the size of violations in Put-Call-Futures Parity and Box Spread relationships

\begin{tabular}{|c|c|c|c|c|}
\hline \multirow{2}{*}{ Variables } & \multicolumn{2}{|c|}{ Put-Call-Futures Parity } & \multicolumn{2}{|c|}{ Box Spread } \\
\hline & Long & Short & Long Box Spread & Short Box Spread \\
\hline \multirow{2}{*}{ Constant } & 500.3380 & -1640.3150 & 112.9259 & -461.6956 \\
\hline & ) $2.24010^{* *}$ & )$-6.7107\left(^{* * *}\right.$ & $2.85811^{* * *}$ & )$-11.4820 e^{* * *}$ \\
\hline \multirow{2}{*}{ M } & 69.3603 & 117.0291 & 12.4436 & 36.4211 \\
\hline & $6.1730 e^{* * *}$ & $9.7225^{* * *}$ & $4.86922^{* * *}$ & ) $14.6074\left(^{* * *}\right.$ \\
\hline \multirow{2}{*}{ V } & -0.0977 & -0.4656 & -0.0376 & 0.2279 \\
\hline & )-0.2837( & )-1.2452( & )-1.0224( & $6.17522^{* * *}$ \\
\hline \multirow{2}{*}{$\mathrm{O}$} & -0.4678 & -0.1536 & -0.0496 & -0.0363 \\
\hline & )$-7.4060\left(^{* * *}\right.$ & )$-2.30500^{* *}$ & )$-7.8291{ }^{* * *}$ & )-5.5747 ( $^{* * *}$ \\
\hline \multirow{2}{*}{$\mathrm{T}$} & 0.9475 & -0.6187 & -2.8293 & 1.3095 \\
\hline & 0.6959 ( & )-0.4245( & )$-11.1791(* * *$ & $5.1355^{(* *}$ \\
\hline \multirow{2}{*}{ E } & -1.5639 & 1.2950 & -0.2243 & 0.2239 \\
\hline & )$-5.0953{ }^{* * *}$ & $3.90122^{* * *}$ & )$-4.3318 e^{* * *}$ & $4.27944^{(* *}$ \\
\hline \multirow{2}{*}{$\mathrm{DE}$} & $\mathrm{n} / \mathrm{a}$ & $\mathrm{n} / \mathrm{a}$ & 1.1030 & 0.3485 \\
\hline & $\mathrm{n} / \mathrm{a}$ & $\mathrm{n} / \mathrm{a}$ & $(4.4301)^{* * *}$ & (1.3991) \\
\hline \multirow{2}{*}{$\mathrm{D}$} & 555.5963 & -178.5749 & 201.9636 & -151.2147 \\
\hline & $(3.8822)^{* * *}$ & $(-1.1744)$ & $(8.5394)^{* * *}$ & $(-6.2908)^{* * *}$ \\
\hline $\begin{array}{l}\text { Number of } \\
\text { observations }\end{array}$ & 11903 & 11903 & 28985 & 28985 \\
\hline p-value & 0.0000 & 0.0000 & 0.0000 & 0.0000 \\
\hline
\end{tabular}

\section{Conclusion}

This paper compares the violations of some well-known arbitrage pricing relationships, Put-Call-Futures Parity and Box Spread, before and after the adjustment of SET50 Index Options contract on October 29, 2012 and examines the determinants of the size of violations in SET50 Index Options pricing relationships. Using daily data from October 29, 2007 to December 30, 2016, we conduct violation tests under 2 scenarios. The closing 
prices are used in scenario 1 when ignoring transaction costs. The closing prices are replaced by the bid and ask prices in Scenario 2 when considering transaction costs. The results show that the possibility to realize an arbitrage profit from the violations becomes irrelevant in Scenario 2. With respect to the Put-Call-Futures Parity, the frequency and the size of violations in many cases are observed more in the period before contract adjustment. Moreover, many more violations of the Box Spread condition are detected before (after) the modification of SET50 Index Options when excluding (including) transaction costs. However, the baht amount of the Box Spread violations in many cases is greater in the period after change in contract specification. For the estimation of Tobit model, the violation sizes of both Put-Call-Futures Parity and Box Spread, excluding transaction costs, depend on the liquidity of SET50 Index Options market measured by option moneyness and open interest. In the case of either options being farther from the money or open interest being low, the size of violations is larger to reflect a premium for liquidity risk. The amount of arbitrage profits also depend on exercise price and option contract adjustment, though the signs of estimated coefficients are mixed. Time to maturity significantly has an impact only on violations of Box Spread. Therefore, investors, who want to earn profits from the violations of SET50 Index Options pricing relationships, can make investment decisions efficiently by taking into account not only the liquidity of SET50 Options market but also some specifications of SET50 Options contract, especially exercise price.

\section{Acknowledgments}

The author acknowledges financial support from Department of Economics, Kasetsart University

\section{References}

Ackert, L. F., \& Tian, Y. S. (2001). Efficiency in Index Options Markets and Trading in Stock Baskets. Journal of Banking \& Finance, 25(9), 1607-1634. https://doi.org/10.1016/S0378-4266(00)00145-X

Dixit, A., Yadav, S. S., \& Jain, P. K. (2011). Testing Lower Boundary Conditions for Index Options Using Futures Prices: Evidences from the Indian Options Market. The Journal for Decision Makers, 36(1), 15-31. https://doi.org/10.1177/0256090920110102

Jongadsayakul, W. (2015). The Study of the Liquidity of SET50 Index Options. Proceedings of 53th Kasetsart University Annual Conference (pp. 413-421). Bangkok, Thailand: Kasetsart University. (In Thai). Retrieved from http://annualconference.ku.ac.th/cd53/12_002_O5.pdf

Jongadsayakul, W. (2016). A Box Spread Test of the SET50 Index Options Market Efficiency: Evidence from the Thailand Futures Exchange. International Journal of Economics and Financial Issues, 6(4), 1744-1749. Retrieved from https://www.econjournals.com/index.php/ijefi/article/viewFile/2741/pdf

Jongadsayakul, W. (2017a). Arbitrage Opportunity in Thailand Futures Exchange: An Empirical Study of SET50 Index Options. 2017 IACB, ICE \& ISEC Proceedings (pp. 381-1-381-7). Maui, HI: The Clute Institute. Retrieved from https://www.cluteinstitute.com/conference-proceedings/HI17Proceedings.pdf

Jongadsayakul, W. (2017b). The Internal Efficiency Test of SET50 Index Options Market: Call Options vs. Put Options. Applied Economics Journal, 24(2), 1-16. (In Thai). Retrieved from https://www.tci-thaijo.org/index.php/AEJ/article/view/103842

Kamara, A. \& Miller, T. W., Jr. (1995). Daily and Intradaily Tests of European Put-Call Parity. Journal of Financial and Quantitative Analysis, 30(4), 519-539. https://doi.org/10.2307/2331275

Lertburapa, J. (2015, September), A Test of Put-Call Future Parity in TFEX. Paper Presented at 8th SEC Working Papers Forum, Bangkok, Thailand. (In Thai). Retrieved from http://www.sec.or.th/TH/Documents/SEC_WPF/sec_wpf_0858_02_re.pdf

Misra, D., \& Misra, S. (2005, February). Determinants of Violation of Put-Call Parity Theorem: A Study of NSE Nifty Options. Paper Presented at 7th GCA, New Delhi, India. Retrieved from https://www.actuariesindia. org/downloads/gcadata/7thGCA/DVPCPT_Dheeraj\%20\&\%20Sangeeta\%20Misra.PDF

Mohanti, D., \& Priyan, P. K. (2013). Ex-ante Test of Lower Boundary Condition and Market Efficiency: Evidence from Indian Index Options Market. NMIMS Management Review, 23, 65-84. Retrieved from http://www.nmims.edu/NMIMSmanagementreview/pdf/april-may-2013/04-Exante-Text-Lower-BoundaryCondition-Market-Efficiency.pdf

Tobin, J. (1958). Estimation of Relationships for Limited Dependent Variables. Econometrica, 26(1), 24-36. https://doi.org/10.2307/1907382

Tucker, A. L. (1991). Financial futures, options, and swaps. St. Paul, MN: West Publishing Company. 
Vipul. (2009). Box-Spread Arbitrage Efficiency of Nifty Index Options: The Indian Evidence. Journal of Futures Markets, 29(6), 544-562. https://doi.org/10.1002/fut.20376

\section{Copyrights}

Copyright for this article is retained by the author(s), with first publication rights granted to the journal.

This is an open-access article distributed under the terms and conditions of the Creative Commons Attribution license (http://creativecommons.org/licenses/by/4.0/). 